\title{
Implicațiile factorilor cognitivi şi de personalitate în luarea deciziilor - un model teoretico-explicativ
}

\author{
Delia Vîrgă \\ Universitatea de Vest din Timişoara
}

\begin{abstract}
This study is aimed to show the influence of cognitive and non-cognitive factors on decisional efficiency through the design of a theoretical-explicative model and by testing it against reality. This model reflects the link between cognitive variables, personality variables and decisional performance.

The participants in this study $(\mathrm{N}=88)$ are managers in a IT\&C company and have an average age of 32.3 years and a average working seniority of 8.6 years, $74.9 \%$ being males and $25.1 \%$ being females.

The instruments used were California Psychological Inventory (CPI 260 items form), a questionnaire for assessing the decisional style, a decision making questionnaire, decisional skills test (BTPAC), and Raven standard test, Plus form, a questionnaire for assessing cognitive complexity and Melbourne decision making questionnaire. In order to evaluate decisional performance I developed an behaviorally anchored scale.

The evaluation of cognitive competencies, defined in behavioral terms like decision making performance and cognitive complexity, together with the personality dimensions, help us to select managers with an increased adaptive orientation to organizational change and a better decisional performance.
\end{abstract}

Key words: decision making performance, cognitive complexity, organizational change.

\section{Résumé}

Cette étude vise à montrer l'influence des facteurs cognitifs et non-cognitifs sur l'efficacité de la décision par l'élaboration d'un modèle théorique explicative qu'on le teste face la réalité. Ce modèle reflète le lien entre les variables cognitives, les variables de la personnalité et la performance décisionnelle.

Les participants à cette étude $(N=88)$ sont des cadres dans une compagnie IT \& $C$ qu'ils ont une moyenne d'âge de 32,3 ans et une expérience de travail moyenne de 8,6 ans, 74,9\% étaient hommes et $25,1 \%$ femmes.

Les instruments utilisés étaient California Psychological Inventory (CPI -la forme avec 260 items), un questionnaire pour évaluer le style décisionnel, un questionnaire de prise de décision, un test décisionnel (BTPAC), et le test standard Raven, la forme Plus, un questionnaire d'évaluation de la complexité cognitive et le questionnaire Melbourne de la prise de décision. Afin d'évaluer la performance de décision, on a développé une échelle avec des ancres comportementales.

L'évaluation des compétences cognitives, définis en termes de comportement comme la performance de prise de décision et la complexité cognitive, avec les dimensions de la personnalité, nous aident à sélectionner les cadres avec une orientation accrue d'adaptation au changement organisationnel et avec une meilleure performance décisionnel.

Mots clés : performance en prise de décision, complexité cognitive, changement organisationnel.

Acest studiu are ca scop evidențierea influenței factorilor cognitivi vs. non-cognitivi asupra eficienței decizionale, prin construirea şi testarea unui model teoretico-explicativ care

\footnotetext{
${ }^{1}$ Adresa de corespondență: delia.virga@apio.ro
}

evidențiază legătura dintre variabilele cognitive, variabilele de personalitate şi performanța decizională.

Programele de schimbare organizațională şi, în special, dezvoltarea organizațională sugerează optimizarea 
performanțelor individuale şi ale organizației prin îmbunătățirea strategiilor de schimbare atât la nivelul conducerii organizațiilor, cât şi la nivelul sistemelor şi structurilor lor. Decizia este un fenomen cheie în implementarea şi susținerea schimbărilor organizaționale iar adaptabilitatea la schimbare tinde să devină o cerință imperioasă pentru selecția şi evaluarea personalului, fiind deja un deziderat al organizațiilor în schimbare. De-a lungul timpului au fost elaborate mai multe modele de luarea deciziei, în special, sau de explicare a cauzelor şi mecanismelor funcționale ale managerilor în diferite contexte organizaționale, cum ar fi stresul ocupațional (Pitariu, 2004). Este important să studiem factorii individuali (atât de natură cognitivă, cât şi cei legați de personalitate) care pot anticipa succesul decizional pentru a putea să identificăm, pe baza acestora, persoanele care au potențial să adopte decizii eficiente în medii organizaționale dinamice şi complexe, specifice situației de schimbare organizaționale.

Actorii organizaționali trebuie să fie instruiți astfel încât să-şi înțeleagă propriile reacții la schimbare sau reacțiile proprii față de alți membri ai organizației, în condițiile schimbării. Ei trebuie să ajungă să gândească organizația ca sistem complex adaptativ şi să conştientizeze faptul că dezvoltarea organizațională este direct dependentă de gradul personal de adaptabilitate. Capacitatea de adaptare creşte pe măsură ce se observă, analizează şi se diagnostichează problema cu care se confruntă oamenii din organizații, dar şi organizația în sine.

Managementul resurselor umane într-un mediu dinamic se poate realiza cu succes dacă sunt angajați indivizi care sunt capabili şi doresc să muncească într-un mediu în schimbare. De aceea, sistemele de selecție din organizații trebuie să identifice persoanele care au o mare capacitate de adaptare la schimbarea organizațională (Vîrgă, 2004).

În contextul organizațional, decizia la nivel individual presupune valorizarea factorilor psihologici de natură cognitivă, în special, în estimarea eficienței decizionale. Complexitatea cognitivă este 0 variablă individuală care sprijină procesul decizional în condițiile încărcării informaționale, incertitudinii şi presiunii timpului. Capacitatea decizională reprezintă evaluarea raționalității decidentului, respectiv sensibilitatea la erori şi euristici cognitive. Aptitudinile cognitive generale sunt garanția unui demers logico-formal în derularea procesului decizional performant. Factorii ce țin de structura de personalitate intevin în situații de schimbare organizațională şi au valoare predictivă în performanța din situațiile decizionale stresante. Aceste situații generează stres față de care managerii performanți dezvoltă modalități eficiente de control al stresului iar stilul de luarea deciziei este o variabilă de interfață între personalitate şi mediu, respectiv situația decizională. În condiții de stabilitate organizațională, decizia are caracteristici bine precizate şi se pot folosi rutine în abordarea ei sau comportamente bazate pe reguli. În aceste condiții sunt importanți anumiți factori psihologici, în special cei care corespund laturii cognitive. În condiții de schimbare, nevoia de adaptare generează potențarea unor variabile mai nuanțate de factură cognitivă şi de personalitate.

Teoria procesării informației relevă limitele raționalității decidenților şi modalitățile adaptative folosite de aceştia în vedea adaptării la complexitatea şi dinamica mediului organizațional. Cercetările recente susțin ideea că decizia în contexte de schimbare impune cerințe deosebite față de decizia în contexte stabile, în care informația este procesată mai mult sau mai puțin automat iar cerințele comportamentale sunt explicite. Un alt rezultat interesant este că diferențele individuale de adaptabilitate (exprimate prin factori de personalitate) sunt predictori mai buni decât aptitudinile cognitive generale.

Pornind de la aceste premise, am considerat că variabilele psihologice, atât cele cognitive, cât şi cele de personalitate, în context organizațional influențează performanța decizională, în condițiile schimbărilor rapide de mediu, fiind predictori ai adaptabilității la schimbare. Identificarea influenței variabilelor individuale şi organizaționale asupra performanței decizionale, în contextul schimbării organizaționale, creează premisa identificării adaptabilității la schimbare, precum şi modelarea atitudinilor şi comportamentelor adaptative ale actorilor implicați în programe de schimbare organizațională.

Modelul proiectat de noi are ca scop identificarea relațiilor dintre factorii cognitivi şi de personalitate care contribuie la predicția performanței decizionale din organizațiile în schimbare. Modelul vizează nivelul individual al deciziei, în context organizațional, nu la nivel de mecanism de realizare a procesului 
deciziei, ci se referă la factori psihologici care pot estima succesul ca decidenți ai managerilor din organizațiile în schimbare.

Pentru a identifica influența factorilor
cognitivi şi de personalitate asupra performanței decizionale în condiții de schimbare organizațională, s-a proiectat un model teoretic care trebuie verificat empiric, în context organizațional real (Figura 1).

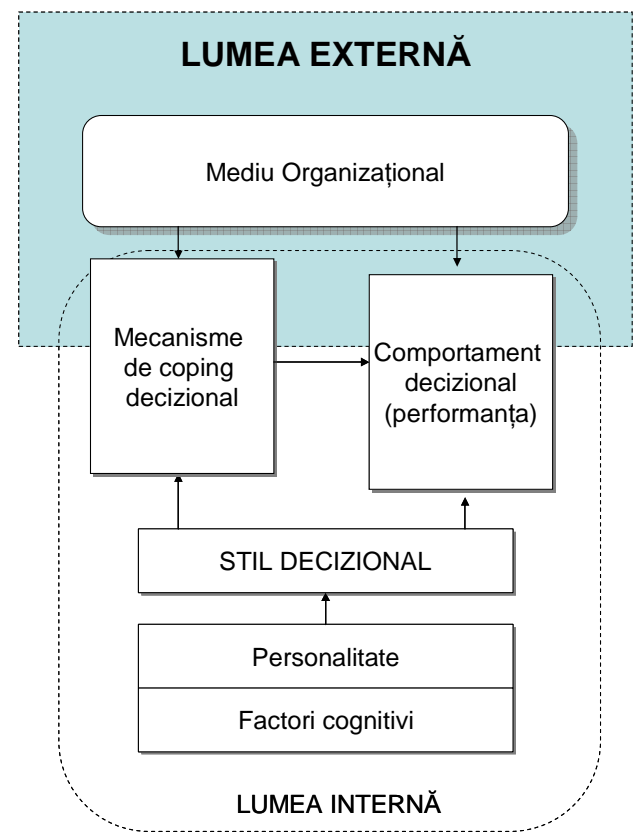

Figura 1. Modelul teoretico-explicativ al deciziei la nivel individual

Prin acest model, cercetarea dobândeşte un caracter mixt, atât explicativ prin izolarea şi identificarea influenței celor două categorii de variabile: cognitive şi de personalitate asupra performanței decizionale, cât şi predictiv, prin posibilitate de a estima performanța decizională la nivel organizațional pentru potențialii candidați în procesul de selecție, pe baza unor predictori testați anterior.

În categoria factorilor cognitivi incluşi în model se găsesc: aptitudinile cognitive generale, capacitatea decizională şi complexitatea cognitivă.

Aptitudinea cognitivă poate fi definită ca fiind capacitatea fundamentală de gândire şi încorporează componente ale abilității de învățare şi adaptare (Jensen, 1980, Schmidt, 2002). Este înțeleasă ca fiind capacitatea de procesare a informațiilor complexe sau capacitatea de a rezolva problemele din viața reală (Flynn, 1987).

Aptitudinile cognitive generale sunt unele dintre cele mai puternice diferențe individuale folosite ca predictori ai performanței în sarcină, dincolo de situații, organizații sau posturi. Evaluarea aptitudinilor cognitive este necesară într-o piață globală de mare competitivitate. Este necesar însă să luăm în calcul şi alte variabile cognitive care să exploreze mai nuanțat potențialul adaptativ al managerilor la schimbarea organizațională. Capacitatea decizională, definită ca sensibilitatea la erori şi euristici cognitive, ne poate ajuta să evaluăm modul în care managerii rezistă la aceste erori decizionale datorită capacității limitate de procesare a informației.

Complexitatea cognitivă se referă la abilitatea de a diferenția perspective alternative şi de a integra aceste perspective în procesul luării deciziei. Complexitatea cognitivă ridicată presupune folosirea de către indivizi a unui mare număr de dimensiuni în perceperea şi evaluarea mediului; aceştia fac diferențe subtile şi nuanțate, ceea ce ajută la tolerarea mai bună a ambiguității şi incertitudinii, respectiv la creşterea capacității adaptative la dinamica mediului organizațional.

Cercetările din ultimii 40 de ani au demonstrat că dimensiunile personalității au un impact puternic asupra performanței în muncă şi asupra altor criterii relevante din organizații (cum ar fi, absenteismul, comportamentul 
contraproductiv, promovarea, fluctuația de personal) şi, în consecință, sunt acum acceptate ca instrumente utile în selecția de personal şi incluse în multe modele de performanță a muncii (Hunter, Schmidt, Rauschenberger şi Jayne, 2001). De asemenea, Anderson şi Cunningham-Snell (2000) au demonstrat că testele de personalitate măsoară variabile care nu pot fi evaluate prin alte metode de selecție şi furnizează o varianță unică în explicarea criteriului.

Stilul decizional a fost definit ca fiind „modelul de răspuns obişnuit manifestat de un individ confruntat cu o situație decizională. Stilul decizional nu este o trăsătură de personalitate, ci o reacție bazată pe obişnuință într-un context decizional" (Scott şi Bruce, 1995).

Vigilența este considerată o strategie adaptativă în luarea deciziei pe când evitarea defensivă manifestată ca evitare, amânare sau hipervigilență sunt considerate strategii maladaptative. Luarea deciziei în manieră vigilentă este 0 activitate cognitivă complexă. Persoanele care optează pentru acest stilul vigilent de control al stresului sunt caracterizate printr-o complexitate cognitivă, adică o capacitate de a interpreta problemele în multiple feluri şi folosirea unui număr mare de dimensiuni în realizarea raționamentelor. De asemenea, au o mare nevoie de cunoaştere, respectiv de a procesa informația într-o manieră elaborată. $\mathrm{Pe}$ de altă parte, persoanele hipervigilente au o intoleranță la ambiguitate şi un stil intuitiv, de încercare şi eroare în rezolvarea situațiilor decizionale.

S-a presupus că nevoia de adaptabilitate la schimbarea organizațională implică valorizarea mai nuanțată a factorilor cognitivi implicați în performanța decizională. De asemenea, se estimează accentuarea în mai mare măsură a influenței factorilor de personalitate asupra capacității adaptative a managerilor.

Variabilele de tip stil: stil decizional rațional şi vigilența ca stil de management adaptativ la stresul decizional, au valoare de variabile mediatoare în cadrul modelului dar şi de indicatori ai abordării adaptative în luarea deciziilor din situații de schimbare organizațională.

Performanța decizională a fost considerată un tip specific de performanță în sarcină şi este importantă în activitatea managerială în care complexitatea sarcinilor valorizează în mai mare măsură factorii cognitivi iar nevoia de decizii corecte este imperios necesară.

Modelul propus de noi a fost testat în condiții organizaționale reale, la nivel managerial. Pe baza lui, se pot identifica predictori ai eficienței decizionale în contextul schimbării organizaționale, necesari performanței adaptative a managerilor.

Decizia este un prim pas al soluției adoptate pentru a implementa schimbarea organizațională şi este influențată de aptitudinile cognitive şi de trăsăturile de personalitate ale managerilor, de stilul decizional, precum şi de mecanismul de apărare folosit de aceştia în situațiile de conflict decizional.

Identificarea influentei variabilelor cognitive şi de personalitate asupra eficienței deciziei creează premisa modelării atitudinilor şi comportamentelor decizionale ale managerilor implicați în programe de schimbare organizațională.

\section{Obiectivele cercetării}

Cercetarea îşi propune identificarea factorilor psihologici care contribuie la succesul ca decidenți a managerilor din organizațiile în schimbare, iar ipoteza de la care porneşte este că factorii cognitivi şi de personalitate acționează într-o manieră diferită, mai nuanțată, în predicția performanței decizionale în condiții de schimbare organizațională, față de condițiile de stabilitate organizațională.

\section{Metodologia cercetării}

Această cercetare este o cercetare explorativă, ce vizează discutarea unui model teoretico-explicativ prin care se urmăreşte identificarea predictorilor ce duc la performanța decizională din organizațiile în schimbare.

\section{Participanți}

Participanții la cercetare sunt 88 de subiecți care ocupă poziții manageriale în organizația studiată.

Vârsta medie a participanților a fost 32.3 ani (variind între minim 22 ani şi maxim 56 ani).

Vechimea medie în muncă a fost de 8.6 ani. Vechimea medie pe postul actual a fost 3.1 ani.

Distribuția în funcție de sex arată că $74.9 \%$ dintre subiecți sunt bărbați şi $25.1 \%$ femei, după cum relevă Figura 2. 


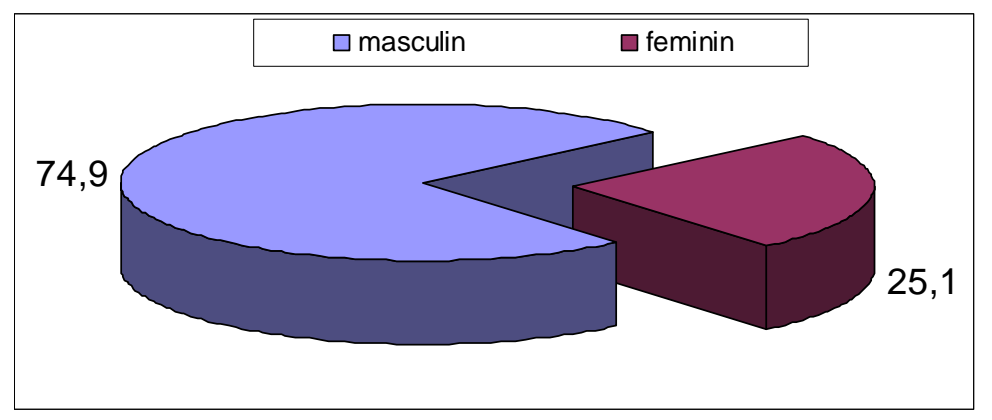

Figura 2. Distribuția subiecților pe sexe

\section{Instrumente}

Inventarul Psihologic California (CPI) (Gough, 1987) este un chestionar creion-hârtie cu auto-administrare compus din 260 itemi, afirmații (folk concepts) pe care subiectul trebuie să le marcheze dacă din punctul lui de vedere le consideră "adevărate" sau "false". CPI evaluează trăsăturile de personalitate în context de normalitate, pune în evidență comportamentul persoanei în relațiile interpersonale cotidiene (Gough, 1987). Adaptarea pentru populația românească a fost realizată de prof. univ. dr. Horia D. Pitariu. Scalele care intră în componența CPI şi pe care le-am utilizat, sunt următoarele: Dominanță (Do), Capacitatea de statut (Cs), Sociabilitatea (Sy), Prezența socială (Sp), Acceptarea de sine (Sa), Independența (In), Empatia (Em), Responsabilitatea (Re), Conformismul social (So), Autocontrolul (Sc), Impresia bună (Gi), Comunalitatea $(\mathrm{Cm})$, Sănătatea $(\mathrm{Wb})$, Toleranța (To), Realizarea prin conformism (Ac), Realizarea prin independență (Ai), Fluență conceptuală (Cf), Sensitivitate (Sn), Flexibilitatea (Fx), Perspicacitate (Is), Potențial managerial (Mp), Orientare spre muncă (Wo), Temperament creativ (Ct), Leadership (Lp), Amicalitate (Ami), Orientare spre aplicarea legii (Leo), Ostilitate (Hos), Luptător (Fght), organizate în următoarele dimensiuni:

- Relaționarea cu alții;

- Managementul de sine;

- Motivație şi stil de gândire;

- Caracteristici personale;

- Măsuri legate de muncă.

Modelul teoretic cuboid dezvoltat de $\mathrm{H}$. Gough descrie patru stiluri de viață sau tipuri de oameni (Alfa, Beta, Gama şi Delta) definite prin combinarea a doi vectori, v1 şi v2, un al treilea, v3 explicând nivelul de realizare (Pitariu şi lliescu, 2006).
Chestionarul de stil decizional general (GDMS) a fost dezvoltat în SUA de Scott şi Bruce (1995) pe baza unui eşantion de ofițeri de armată şi studenți ca răspuns la nevoia de a avea un instrument de determinare stilul de luarea deciziei, la nivel individual, pornind de la premisa că există diferențe individuale în ceea ce priveşte modul de evaluare şi selecție a alternativelor decizionale. Studiile ulterioare au oferit un suport empiric considerabil pentru acest chestionar (Loo, 2000). Chestionarul, format din 25 de itemi, oferă scorurile la cinci stiluri de decizie preferate:

- Stilul rațional,

- Stilul dependent;

- Stilul ezitant;

- Stilul intuitiv;

- Stilul spontan.

Cei 25 de itemi sunt prezentați subiecților împreună cu o scală de tip Likert cu 5 trepte, de la dezacord puternic la acord puternic, fiind precedați de următoarea afirmație: „Următoarele afirmații descriu felul în care oamenii iau decizii importante. Va rugăm să indicați gradul Dvs. de acord sau dezacord pentru fiecare afirmație."

Scalele GDMS sunt valide pentru eşantioane de ofițeri militari, studenți, ingineri şi tehnicieni, coeficienții Cronbach $\boldsymbol{\alpha}$ variind între: 0.77-0.85 pentru stilul Rațional; 0.78 0.84 pentru stilul Intuitiv; 0.62-0.86 pentru stilul Dependent; 0.84-0.94 pentru stilul Evitant şi între 0.83-0.87 pentru stilul Spontan (Loo, 2000, Scott \& Bruce, 1995).

Testul de capacitate decizională face parte din Bateria BTPAC şi evaluează raționalitatea decidentului, respectiv "sensibilitatea redusă la erorile decizionale". 
Testul a fost realizat pe baza cercetărilor celebrilor A. Tversky şi D. Kahneman în domeniul raționalității limitate şi a constat în standardizarea unor situații experimentale. Testul conține 14 itemi care descriu situații decizionale şi prezintă alternativele pentru care pot opta subiecții, fiind construiți sub forma unor situații $\mathrm{cu}$ răspunsuri la alegere. Consistența internă a probei este 0,61 (coeficientul Alfa Cronbach).

\section{Testul Matricele Progresive}

Standard, forma Plus, a fost elaborate de J. Raven şi adaptat pe populația românească în 2003 (coordonator Anca Domuța). Această formă a fost elaborată pentru a discrimina în rândul persoanelor care obțin performanțe superioare. Conține 60 de itemi, fiind una dintre cele mai eficiente modalități de evaluare a factorului $g$ sau a funcționării intelectuale generale. Testul Matricele Progresive Standard este alcătuit din 5 serii a câte 12 itemi, fiecare dintre acestea începând cu o problemă simplă şi crescând în dificultate. Studiile au demonstrate proprietățile psihometrice ale probei (vezi Manualul Raven, 2003).

Subiecții trebuie să decidă ce figură dintr-un set de 8 figuri se potriveşte cu un set de alte opt figuri. Scorurile ridicate indică capacitate intelectuală ridicată. Testul este folosit pe scară largă pentru a evalua inteligența generală şi este etalonat pentru diferite tipuri de populații.

Chestionar de complexitate

cognitivă cuprinde 22 de itemi si conține 5 scale: metacogniție, influență socială, dorință de cunoaştere, toleranță la ambiguitate şi deschidere spre nou. Măsoară capacitatea de procesare a informatiilor din surse multiple. Complexitatea cognitivă se referă la abilitatea de a diferenția perspective alternative şi de a integra aceste perspective în procesul luării deciziei. Consistența internă pentru întreg chestionarul este egală cu .74 (N=195), ceea ce semnifică o consistență internă adecvată.

$$
\text { Chestionarul de decizie }
$$

Melbourne (MDMQ), elaborat de Mann (1997), este un instrument de măsurare a mecanismelor de apărare în conflictul decizional. Conține patru scale: vigilența ( 6 itemi, alfa Cronbach $=.80)$, hipervigilența ( 5 itemi, alfa Cronbach $=.74)$, amânare $(5$ itemi, alfa Cronbach $=.81)$ şi evitare $(6$ itemi, alfa Conbach $=.87$ ), scale ce sunt evidențiate de răspunsurile la 22 de itemi. Acest chestionar a fost obținut prin modificarea chestionarului de decizie Flinders, elaborat de Mann (1982), care conținea 6 scale şi 31 de itemi. Mann (1982) a dezvoltat chestionarul inițial bazându-se pe definițiile, descrierile şi exemplele modelelor de control al stresului decizional descrise de Janis şi Mann (1977).

Pentru performanța decizională sa utilizat o scală de evaluare cu ancore comportamentale construită pe baza specificului organizației, pe baza algoritmului prezentat in literatura de specialitate (Pitariu, 2000).

\section{Procedura}

Instrumentele de evaluare a dimensiunilor psihologice prezentate au fost aplicate colectiv, în mai multe sesiuni de lucru, organizate la nivel departamental, întregului eşantion de subiecți selectați din organizația studiată.

Testarea modelului a fost realizată în mediu organizațional natural, respectiv într-o companie multinațională din domeniul telecomunicațiilor, numită Alfa. Momentul testării a coincis cu debutul unei perioade de profunde schimbări la nivel strategic, care s-au reflectat în mod diferit la nivel organizațional şi departamental. Organizația este structurată pe cinci departamente dintre care patru produc soft pentru telefonie fixă, mobilă, transmisia de date pe fibră optică şi servicii conexe telefoniei mobile şi un departament de operațiuni care oferă suport tehnic la clienți pentru instalarea, întreținerea şi îmbunătățirea centralelor telefonice. Pe lângă aceste departamente tehnice, mai există şi departamente de suport: financiar, resurse umane şi unul de ofertare care este localizat în Bucureşti. Cercetarea a fost derulată în departamentele tehnice din Timişoara, cu acordul organizației şi cooperarea directorilor de departament.

\section{Rezultate}

Distribuția preferințelor pentru stiluri decizionale în compania Alfa, prezentată în Figura 3 indică faptul că stilul dominant este cel rațional. 




Figura 3. Preferințe pentru stilul decizional în compania Alfa (medii)

Stilul decizional rațional presupune o preferință puternică pentru folosirea logicii şi raționamentului în luarea deciziilor. Atunci când sunt luate decizii subiecții ce preferă stilul rațional utilizează deseori analize de tip costbeneficiu sau SWOT.
Cel mai puțin preferat este stilul decizional spontan, care presupune decizii rapide, impulsive, bazate pe analize sumare ale contextelor.

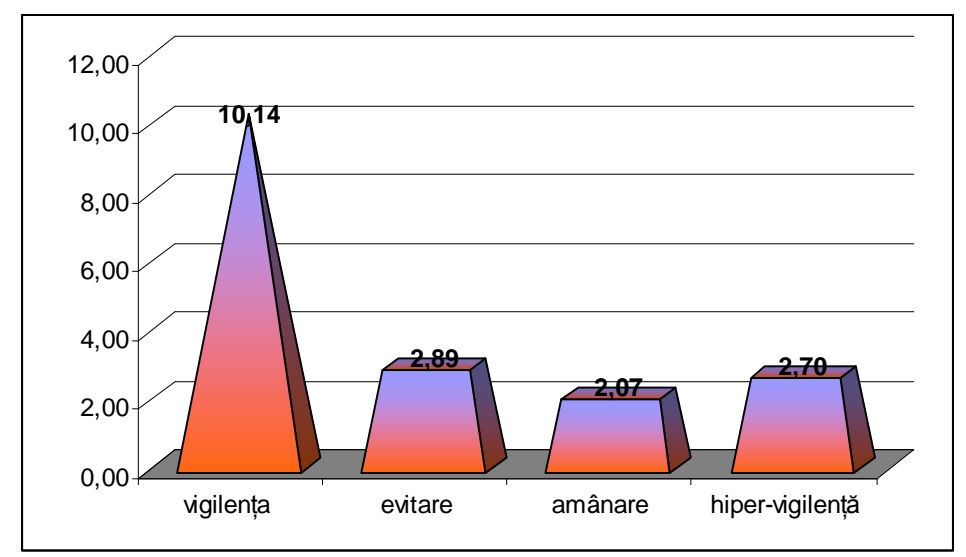

Figura 4. Preferințe pentru mecanisme de apărare în cazul conflictelor decizionale în compania Alfa

Din Figura 4 rezultă că mecanismul de apărare preferat în cazul unui conflict decizional este vigilența, ce presupune opțiuni pentru clarificarea obiectivelor care trebuiesc atinse prin luarea deciziei, căutarea atentă a informațiilor relevante, asimilarea fără prejudecăți a informațiilor şi evaluarea prudentă a alternativelor înainte de luarea unei decizii.
În continuare, s-a calculat media şi abaterea standard a variabilelor studiate, atât la nivelul întregului eşantion studiat, cât şi la nivel subeşantioanelor formate din persoane care ocupă funcții manageriale şi cei care au funcții executive. Datele sunt reprezentate în Tabelul 1. 
Tabelul 1. Statistici descriptive pentru variabilele studiate

\begin{tabular}{|c|c|c|c|c|c|c|c|c|c|}
\hline & & $\begin{array}{l}\text { Medie } \\
\text { Eşantion } \\
\text { total, } \\
\mathrm{N}=196 \\
\end{array}$ & $\begin{array}{l}\text { Ab. } \\
\text { Std }\end{array}$ & Min & Max & $\begin{array}{l}\text { Medie } \\
\text { Manageri } \\
\mathrm{N}=88 \\
\end{array}$ & $\begin{array}{l}\text { Ab. } \\
\text { Std }\end{array}$ & $\begin{array}{l}\text { Medie } \\
\text { Non-manageri } \\
\mathrm{N}=108 \\
\end{array}$ & $\begin{array}{l}\text { Ab. } \\
\text { Std }\end{array}$ \\
\hline \multirow{35}{*}{ Scale CPI } & $\mathrm{DO}$ & 20,04 & 4,61 & 7 & 27 & 20,98 & 3,78 & 19,27 & 5,08 \\
\hline & CS & 12,61 & 2,52 & 3 & 18 & 12,58 & 2,31 & 12,63 & 2,70 \\
\hline & SY & 15,85 & 4,08 & 4 & 21 & 16,28 & 3,69 & 15,49 & 4,36 \\
\hline & SP & 17,84 & 3,86 & 7 & 28 & 17,43 & 3,64 & 18,18 & 4,02 \\
\hline & SA & 13,81 & 3,07 & 6 & 20 & 13,86 & 2,79 & 13,77 & 3,30 \\
\hline & IN & 14,37 & 2,55 & 6 & 19 & 14,76 & 2,45 & 14,06 & 2,59 \\
\hline & EM & 14,37 & 2,99 & 6 & 24 & 14,32 & 2,72 & 14,41 & 3,20 \\
\hline & $\mathrm{RE}$ & 17,56 & 2,68 & 9 & 22 & 17,44 & 2,48 & 17,65 & 2,84 \\
\hline & SO & 26,51 & 2,98 & 16 & 32 & 26,56 & 3,24 & 26,46 & 2,77 \\
\hline & SC & 19,10 & 3,76 & 8 & 27 & 19,07 & 4,06 & 19,13 & 3,51 \\
\hline & $\mathrm{GI}$ & 20,63 & 4,87 & 10 & 30 & 20,45 & 4,85 & 20,77 & 4,91 \\
\hline & $\mathrm{CM}$ & 18,18 & 1,20 & 15 & 20 & 18,10 & 1,15 & 18,25 & 1,25 \\
\hline & WB & 16,28 & 2,26 & 9 & 20 & 16,23 & 2,29 & 16,32 & 2,25 \\
\hline & TO & 12,83 & 2,83 & 7 & 18 & 12,63 & 2,64 & 13,00 & 2,98 \\
\hline & $A C$ & 24,23 & 3,10 & 13 & 29 & 24,61 & 2,99 & 23,93 & 3,17 \\
\hline & $\mathrm{Al}$ & 15,23 & 2,73 & 7 & 21 & 15,05 & 2,55 & 15,38 & 2,87 \\
\hline & $\mathrm{CF}$ & 23,20 & 3,09 & 14 & 28 & 23,43 & 2,83 & 23,01 & 3,29 \\
\hline & IS & 13,77 & 2,03 & 8 & 19 & 13,72 & 2,19 & 13,81 & 1,90 \\
\hline & $\mathrm{FX}$ & 7,97 & 3,53 & 1 & 17 & 7,60 & 3,07 & 8,27 & 3,85 \\
\hline & $\mathrm{SN}$ & 8,18 & 2,52 & 4 & 14 & 7,98 & 2,41 & 8,35 & 2,61 \\
\hline & MP & 16,16 & 3,52 & 7 & 24 & 16,51 & 3,16 & 15,87 & 3,77 \\
\hline & WO & 19,54 & 2,61 & 14 & 25 & 19,41 & 2,34 & 19,64 & 2,82 \\
\hline & CT & 15,20 & 3,22 & 8 & 23 & 14,82 & 3,27 & 15,51 & 3,16 \\
\hline & LP & 40,30 & 6,34 & 23 & 50 & 40,84 & 5,93 & 39,85 & 6,65 \\
\hline & AMI & 19,81 & 3,60 & 8 & 26 & 19,65 & 3,54 & 19,94 & 3,66 \\
\hline & LEO & 18,42 & 2,70 & 10 & 23 & 18,70 & 2,75 & 18,19 & 2,65 \\
\hline & $\mathrm{TM}$ & 13,43 & 1,99 & 7 & 18 & 13,75 & 1,66 & 13,17 & 2,20 \\
\hline & BMS & 29,23 & 5,50 & 16 & 38 & 29,33 & 4,77 & 29,15 & 6,05 \\
\hline & BFM & 13,91 & 2,69 & 6 & 22 & 13,69 & 2,73 & 14,08 & 2,66 \\
\hline & ANX & 3,55 & 1,18 & 0 & 6 & 3,68 & 1,19 & 3,44 & 1,17 \\
\hline & NAR & 18,69 & 4,68 & 9 & 32 & 19,44 & 4,77 & 18,07 & 4,55 \\
\hline & DSD & 17,38 & 2,76 & 11 & 23 & 17,28 & 2,61 & 17,46 & 2,89 \\
\hline & DAC & 12,55 & 2,45 & 5 & 19 & 12,39 & 2,29 & 12,69 & 2,59 \\
\hline & HOS & 7,47 & 2,96 & 0 & 15 & 7,44 & 2,72 & 7,50 & 3,15 \\
\hline & $\mathrm{FF}$ & 14,38 & 2,57 & 6 & 20 & 14,68 & 2,29 & 14,13 & 2,77 \\
\hline \multicolumn{2}{|c|}{ Capacitate intelectuală - Raven } & 31 & 40,35 & 5,00 & 54 & 41,00 & 5,71 & 39,81 & 4,28 \\
\hline \multicolumn{2}{|c|}{ Capacitate decizională } & 1 & 5,33 & 1,76 & 9 & 5,83 & 1,56 & 4,92 & 1,82 \\
\hline \multirow{6}{*}{$\begin{array}{l}\text { Complexitate } \\
\text { cognitivă }\end{array}$} & \begin{tabular}{|l|} 
Abilitate \\
metacognitivă \\
\end{tabular} & 23,93 & 3,34 & 15 & 30 & 24,80 & 2,86 & 23,23 & 3,55 \\
\hline & Influență socială & 17,26 & 2,86 & 6 & 24 & 17,74 & 2,66 & 16,87 & 2,97 \\
\hline & \begin{tabular}{|l|}
$\begin{array}{l}\text { Toleranță la } \\
\text { ambiguitate }\end{array}$ \\
\end{tabular} & 17,63 & 2,87 & 6 & 24 & 18,17 & 2,66 & 17,19 & 2,97 \\
\hline & \begin{tabular}{|l|} 
Dorința de \\
Cunoaştere \\
\end{tabular} & 17,24 & 2,76 & 6 & 24 & 17,58 & 2,76 & 16,97 & 2,75 \\
\hline & \begin{tabular}{|l|} 
Orientare spre \\
Nou
\end{tabular} & 19,89 & 2,73 & 6 & 27 & 20,16 & 2,34 & 19,68 & 3,00 \\
\hline & \begin{tabular}{|l|} 
Complexitate \\
Cognitivă - total
\end{tabular} & 96,15 & 9,12 & 76 & 121 & 98,44 & 9,24 & 94,28 & 8,62 \\
\hline \multirow{2}{*}{$\begin{array}{l}\text { Strategii de } \\
\text { control al stresului } \\
\text { decizional }\end{array}$} & Vigilență & 10,14 & 1,43 & 5 & 12 & 10,06 & 1,37 & 10,20 & 1,48 \\
\hline & Evitare & 2,89 & 2,11 & 0 & 11 & 2,51 & 2,16 & 3,19 & 2,03 \\
\hline
\end{tabular}


Studii şi Cercetări

\begin{tabular}{|c|c|c|c|c|c|c|c|c|c|}
\hline & & $\begin{array}{l}\text { Medie } \\
\text { Eşantion } \\
\text { total, } \\
\mathrm{N}=196\end{array}$ & $\begin{array}{l}\text { Ab. } \\
\text { Std }\end{array}$ & Min & Max & $\begin{array}{l}\text { Medie } \\
\text { Manageri } \\
\mathrm{N}=88\end{array}$ & $\begin{array}{l}\text { Ab. } \\
\text { Std }\end{array}$ & $\begin{array}{l}\text { Medie } \\
\text { Non-manageri } \\
\mathrm{N}=108\end{array}$ & $\begin{array}{l}\text { Ab. } \\
\text { Std }\end{array}$ \\
\hline & Amânare & 2,07 & 1,54 & 0 & 8 & 1,89 & 1,42 & 2,21 & 1,62 \\
\hline & Hiper-vigilență & 2,70 & 1,78 & 0 & 10 & 2,69 & 1,62 & 2,70 & 1,92 \\
\hline \multirow{5}{*}{$\begin{array}{l}\text { Stil } \\
\text { decizional }\end{array}$} & Stil Rațional & 21,16 & 2,50 & 14 & 25 & 21,28 & 2,41 & 21,06 & 2,57 \\
\hline & Stil Intuitiv & 17,73 & 2,93 & 8 & 25 & 17,98 & 2,67 & 17,53 & 3,13 \\
\hline & Stil Dependent & 16,13 & 3,39 & 7 & 23 & 16,36 & 3,46 & 15,94 & 3,33 \\
\hline & Stil Spontan & 12,51 & 3,44 & 5 & 23 & 12,07 & 3,38 & 12,87 & 3,47 \\
\hline & Stil Ezitant & 14,63 & 3,18 & 7 & 24 & 14,80 & 3,29 & 14,49 & 3,10 \\
\hline \multirow{4}{*}{$\begin{array}{l}\text { Eficiență } \\
\text { decizională }\end{array}$} & Decizii tactice & 6,00 & 2,72 & 0 & 12 & 6,18 & 2,72 & 5,85 & 2,73 \\
\hline & \begin{tabular}{|l|} 
Nivel de \\
încredere - \\
decizii tactice \\
\end{tabular} & 7,92 & 1,76 & 0 & 10 & 7,99 & 1,75 & 7,86 & 1,77 \\
\hline & Decizii strategice & 5,77 & 2,92 & 0 & 12 & 5,98 & 3,00 & 5,61 & 2,86 \\
\hline & \begin{tabular}{|l|} 
Nivel de \\
încredere - \\
decizii strategice \\
\end{tabular} & 7,22 & 1,81 & 0 & 10 & 7,29 & 1,78 & 7,16 & 1,85 \\
\hline
\end{tabular}

\section{Corelații}

Din corelațiile dintre variabilele de personalitate şi variabilele vârsta şi vechime prezentate în Tabelul 2 rezultă că persoanele din organizație, pe măsură ce avansează în vârstă, devin mai conformiste, dau dovadă de mai puțină flexibilitate, preferă predictibilitatea şi consistența, se simt inconfortabil $\mathrm{cu}$ ambiguitatea, lucrează programat şi planificat, sunt bine organizate, îşi îmbunătățesc relațiile cu oamenii, sunt mai bune în a explica deciziile altora dar devin mai insensibile la sentimentele altora şi orientate spre acțiune. Au tendința de a folosi în mai mică măsură stilul de control ezitant în stresul decizional şi sunt raționali în luarea deciziei.

Tabelul 2. Corelații semnificative între datele demografice, variabilele de personalitate şi cognitive pe tot eşantionul

\begin{tabular}{|c|c|c|c|c|}
\hline & & Vârsta & Vechime & Vechime pe post \\
\hline \multirow[t]{3}{*}{ Vârsta } & $r$ & & 0,949 & 0,386 \\
\hline & $p$ & & 0,000 & 0,000 \\
\hline & $\mathrm{N}$ & & 191 & 188 \\
\hline \multirow[t]{3}{*}{ Vechime } & $\mathrm{r}$ & 0,949 & & 0,400 \\
\hline & $p$ & 0,000 & & 0,000 \\
\hline & $\mathrm{N}$ & 191 & & 188 \\
\hline \multirow[t]{3}{*}{ Vechime post } & $\mathrm{r}$ & 0,386 & 0,400 & \\
\hline & $\mathrm{p}$ & 0,000 & 0,000 & \\
\hline & $\mathrm{N}$ & 188 & 188 & \\
\hline \multirow[t]{3}{*}{ DO - Dominanță } & $\mathrm{r}$ & 0,176 & 0,215 & \\
\hline & $p$ & 0,014 & 0,003 & \\
\hline & $\mathrm{N}$ & 193 & 191 & \\
\hline \multirow[t]{3}{*}{ AC - Realizare prin conformism } & $\mathrm{r}$ & 0,236 & 0,242 & \\
\hline & $p$ & 0,001 & 0,001 & \\
\hline & $\mathrm{N}$ & 193 & 191 & \\
\hline \multirow[t]{3}{*}{ FX - Flexibilitate } & $\mathrm{r}$ & $-0,231$ & $-0,223$ & \\
\hline & $p$ & 0,001 & 0,002 & \\
\hline & $\mathrm{N}$ & 193 & 191 & \\
\hline \multirow[t]{3}{*}{ SN - Sensitivitate } & $\mathrm{r}$ & $-0,141$ & & \\
\hline & $p$ & 0,050 & & \\
\hline & $\mathrm{N}$ & 193 & & \\
\hline \multirow[t]{3}{*}{ LP - Potențial de leadership } & $\mathrm{r}$ & 0,152 & 0,166 & \\
\hline & $p$ & 0,035 & 0,021 & \\
\hline & $\mathrm{N}$ & 193 & 191 & \\
\hline \multirow[t]{3}{*}{ Complexitate Cognitivă } & $\mathrm{r}$ & 0,301 & 0,284 & \\
\hline & $\mathrm{p}$ & 0,000 & 0,000 & \\
\hline & $\mathrm{N}$ & 193 & 191 & \\
\hline \multirow[t]{3}{*}{$\begin{array}{l}\begin{array}{l}\text { Mecanismul de control al stresului } \\
\text { decizional-evitare }\end{array} \\
\end{array}$} & $r$ & $-0,148$ & $-0,169$ & \\
\hline & $p$ & 0,040 & 0,020 & \\
\hline & $\mathrm{N}$ & 193 & 191 & \\
\hline \multirow[t]{3}{*}{ "Stil decizional-rațional } & $\mathrm{r}$ & 0,157 & 0,141 & \\
\hline & $\mathrm{p}$ & 0,029 & 0,052 & \\
\hline & $\mathrm{N}$ & 193 & 191 & \\
\hline
\end{tabular}


În Tabelul 3 sunt prezentate corelațiile dintre variabilele incluse în model. Se observă că aptitudinile cognitive generale corelează semnificativ cu stilul decizional rațional şi cu criteriul de performanță.

Tabelul 3. Corelații între variabilele cognitive şi de personalitate şi cele de stil (rațional şi vigilența) şi criteriu de performanță la nivel executiv

\begin{tabular}{|c|c|c|c|c|c|c|c|c|c|c|c|}
\hline & & \multicolumn{5}{|c|}{ Stil decizional } & \multicolumn{4}{|c|}{$\begin{array}{l}\text { Strategii de control al stresului } \\
\text { decizional }\end{array}$} & \multirow[b]{2}{*}{$\begin{array}{l}\text { Perfor- } \\
\text { manta }\end{array}$} \\
\hline & & Rational & Intuitiv & $\begin{array}{l}\text { Depen- } \\
\text { dent }\end{array}$ & Spontan & Ezitant & Vigilentă & Evitare & Amânare & $\begin{array}{l}\text { Hiper- } \\
\text { vigilentă }\end{array}$ & \\
\hline \multirow{2}{*}{$\begin{array}{l}\text { Capacitate } \\
\text { intelectuală }\end{array}$} & $r$ & 0,217 & $-0,025$ & $-0,228$ & $-0,052$ & 0,068 & $-0,028$ & $-0,082$ & $-0,122$ & $-0,128$ & 0,225 \\
\hline & $p$ & 0,043 & 0,818 & 0,033 & 0,628 & 0,529 & 0,796 & 0,448 & 0,257 & 0,235 & 0,035 \\
\hline & & & & & & & & & & & \\
\hline \multirow{2}{*}{$\begin{array}{l}\text { Capacitate } \\
\text { Decizională }\end{array}$} & $r$ & $-0,008$ & 0,068 & 0,012 & $-0,039$ & $-0,092$ & 0,225 & $-0,046$ & $-0,035$ & $-0,071$ & 0,202 \\
\hline & $\mathrm{p}$ & 0,938 & 0,527 & 0,914 & 0,716 & 0,392 & 0,035 & 0,673 & 0,746 & 0,510 & 0,059 \\
\hline & & & & & & & & & & & \\
\hline \multirow{2}{*}{$\begin{array}{l}\text { Complexitate } \\
\text { Cognitiva }\end{array}$} & $r$ & 0,288 & 0,283 & 0,013 & $-0,134$ & $-0,283$ & 0,089 & $-0,236$ & $-0,149$ & $-0,094$ & $-0,011$ \\
\hline & $p$ & 0,006 & 0,008 & 0,908 & 0,213 & 0,008 & 0,410 & 0,027 & 0,167 & 0,382 & 0,916 \\
\hline \multicolumn{12}{|l|}{ Scale CPI } \\
\hline \multirow[t]{2}{*}{ DO } & $r$ & $-0,027$ & $-0,103$ & $-0,116$ & $-0,353$ & 0,113 & $-0,058$ & $-0,230$ & $-0,230$ & $-0,288$ & $-0,033$ \\
\hline & $p$ & 0,802 & 0,341 & 0,280 & 0,001 & 0,297 & 0,594 & 0,031 & 0,031 & 0,006 & 0,758 \\
\hline \multirow[t]{2}{*}{ CS } & $r$ & $-0,038$ & $-0,044$ & $-0,100$ & $-0,164$ & $-0,024$ & $-0,199$ & $-0,076$ & $-0,148$ & $-0,136$ & $-0,009$ \\
\hline & $p$ & 0,724 & 0,681 & 0,354 & 0,127 & 0,828 & 0,062 & 0,481 & 0,169 & 0,207 & 0,937 \\
\hline \multirow[t]{2}{*}{ SY } & $r$ & $-0,029$ & 0,073 & $-0,134$ & $-0,387$ & 0,203 & $-0,099$ & $-0,291$ & $-0,227$ & $-0,360$ & $-0,054$ \\
\hline & $p$ & 0,791 & 0,499 & 0,212 & 0,000 & 0,058 & 0,359 & 0,006 & 0,033 & 0,001 & 0,620 \\
\hline \multirow[t]{2}{*}{$S P$} & $r$ & $-0,065$ & 0,079 & $-0,189$ & $-0,328$ & 0,123 & $-0,180$ & $-0,196$ & $-0,244$ & $-0,193$ & $-0,095$ \\
\hline & $p$ & 0,546 & 0,464 & 0,078 & 0,002 & 0,255 & 0,093 & 0,067 & 0,022 & 0,071 & 0,381 \\
\hline \multirow[t]{2}{*}{$S A$} & $r$ & 0,020 & $-0,041$ & $-0,120$ & $-0,331$ & 0,025 & $-0,106$ & $-0,336$ & $-0,225$ & $-0,312$ & $-0,234$ \\
\hline & $p$ & 0,857 & 0,707 & 0,266 & 0,002 & 0,821 & 0,324 & 0,001 & 0,035 & 0,003 & 0,029 \\
\hline \multirow[t]{2}{*}{ IN } & $r$ & $-0,090$ & 0,006 & $-0,229$ & $-0,332$ & 0,136 & $-0,246$ & $-0,137$ & $-0,186$ & $-0,201$ & 0,007 \\
\hline & $p$ & 0,407 & 0,954 & 0,032 & 0,002 & 0,205 & 0,021 & 0,203 & 0,082 & 0,061 & 0,948 \\
\hline \multirow[t]{2}{*}{ EM } & $r$ & $-0,070$ & 0,074 & $-0,107$ & $-0,150$ & 0,092 & $-0,107$ & $-0,102$ & $-0,068$ & $-0,134$ & $-0,060$ \\
\hline & $p$ & 0,516 & 0,494 & 0,323 & 0,163 & 0,393 & 0,321 & 0,342 & 0,529 & 0,213 & 0,576 \\
\hline \multirow[t]{2}{*}{$\mathrm{RE}$} & $r$ & 0,058 & 0,069 & 0,090 & $-0,094$ & $-0,024$ & 0,020 & $-0,030$ & $-0,149$ & $-0,043$ & 0,213 \\
\hline & $p$ & 0,594 & 0,522 & 0,407 & 0,383 & 0,824 & 0,856 & 0,782 & 0,166 & 0,691 & 0,047 \\
\hline \multirow[t]{2}{*}{ so } & $r$ & 0,066 & $-0,081$ & $-0,079$ & $-0,202$ & $-0,109$ & $-0,010$ & $-0,064$ & $-0,151$ & 0,015 & 0,090 \\
\hline & $p$ & 0,539 & 0,454 & 0,466 & 0,059 & 0,313 & 0,928 & 0,553 & 0,160 & 0,887 & 0,404 \\
\hline \multirow[t]{2}{*}{ sc } & $r$ & 0,237 & 0,001 & 0,115 & 0,157 & $-0,192$ & 0,115 & 0,097 & $-0,011$ & 0,026 & 0,062 \\
\hline & $p$ & 0,026 & 0,991 & 0,285 & 0,143 & 0,074 & 0,285 & 0,369 & 0,922 & 0,811 & 0,564 \\
\hline \multirow[t]{2}{*}{ GI } & $r$ & 0,194 & 0,035 & 0,098 & $-0,096$ & $-0,177$ & 0,083 & $-0,129$ & $-0,205$ & $-0,120$ & 0,103 \\
\hline & $p$ & 0,070 & 0,749 & 0,362 & 0,373 & 0,098 & 0,443 & 0,231 & 0,056 & 0,267 & 0,339 \\
\hline \multirow[t]{2}{*}{ CM } & $r$ & 0,048 & 0,223 & 0,046 & 0,123 & 0,213 & 0,026 & $-0,054$ & $-0,106$ & 0,116 & $-0,020$ \\
\hline & $p$ & 0,659 & 0,037 & 0,673 & 0,253 & 0,046 & 0,813 & 0,618 & 0,325 & 0,281 & 0,850 \\
\hline \multirow[t]{2}{*}{ WB } & $r$ & 0,147 & 0,080 & $-0,070$ & $-0,172$ & $-0,018$ & $-0,030$ & $-0,166$ & $-0,187$ & $-0,198$ & 0,089 \\
\hline & $p$ & 0,172 & 0,459 & 0,516 & 0,110 & 0,866 & 0,782 & 0,123 & 0,081 & 0,065 & 0,412 \\
\hline \multirow[t]{2}{*}{ TO } & $r$ & 0,129 & 0,089 & $-0,042$ & $-0,075$ & $-0,055$ & $-0,035$ & $-0,091$ & $-0,141$ & $-0,164$ & $-0,017$ \\
\hline & $p$ & 0,230 & 0,412 & 0,700 & 0,490 & 0,608 & 0,743 & 0,399 & 0,191 & 0,126 & 0,871 \\
\hline$A C$ & $r$ & 0,107 & $-0,056$ & 0,013 & $-0,171$ & $-0,002$ & 0,073 & $-0,144$ & $-0,274$ & $-0,122$ & 0,121 \\
\hline & $p$ & 0,323 & 0,605 & 0,907 & 0,112 & 0,983 & 0,499 & 0,182 & 0,010 & 0,257 & 0,261 \\
\hline Al & $r$ & 0,168 & .0,078 & $-0,024$ & 0,048 & 0,008 & 0,213 & 0,108 & 0,132 & $-0,108$ & $-0,143$ \\
\hline & $p$ & 0,118 & 0,472 & 0,824 & 0,660 & 0,941 & 0,047 & 0,316 & 0,222 & 0,318 & 0,184 \\
\hline CF & $r$ & 0,004 & 0,039 & $-0,228$ & $-0,232$ & 0,127 & 0,038 & $-0,080$ & $-0,163$ & $-0,196$ & 0,106 \\
\hline
\end{tabular}




\begin{tabular}{|c|c|c|c|c|c|c|c|c|c|c|c|}
\hline & & \multicolumn{5}{|c|}{ Stil decizional } & \multicolumn{4}{|c|}{$\begin{array}{l}\text { Strategii de control al stresului } \\
\text { decizional }\end{array}$} & \multirow[b]{2}{*}{$\begin{array}{l}\text { Perfor- } \\
\text { manta }\end{array}$} \\
\hline & & Rational & Intuitiv & $\begin{array}{l}\text { Depen- } \\
\text { dent }\end{array}$ & Spontan & Ezitant & Vigilentă & Evitare & Amânare & $\begin{array}{l}\text { Hiper- } \\
\text { vigilență }\end{array}$ & \\
\hline & $p$ & 0,973 & 0,716 & 0,033 & 0,030 & 0,238 & 0,724 & 0,460 & 0,130 & 0,067 & 0,325 \\
\hline \multirow[t]{2}{*}{ IS } & $r$ & 0,026 & 0,052 & $-0,163$ & $-0,153$ & $-0,034$ & $-0,014$ & $-0,064$ & $-0,159$ & $-0,038$ & 0,047 \\
\hline & p & 0,807 & 0,630 & 0,130 & 0,155 & -0,755 & 0,899 & 0,555 & 0,139 & 0,726 & 0,664 \\
\hline \multirow[t]{2}{*}{ FX } & $r$ & -0,140 & 0,021 & $-0,045$ & 0,176 & .0,034 & $-0,019$ & 0,206 & 0,256 & 0,100 & 0,036 \\
\hline & $p$ & 0,193 & 0,844 & 0,679 & 0,101 & 0,753 & 0,859 & 0,054 & 0,016 & 0,354 & 0,736 \\
\hline \multirow[t]{2}{*}{ SN } & $r$ & $-0,257$ & 0,088 & 0,080 & -0,161 & 0,085 & 0,070 & 0,181 & 0,168 & 0,051 & 0,311 \\
\hline & p & 0,016 & 0,417 & 0,460 & 0,133 & 0,430 & 0,516 & 0,091 & 0,118 & 0,636 & 0,003 \\
\hline \multirow[t]{2}{*}{ MP } & $r$ & 0,238 & $-0,108$ & $-0,010$ & $-0,190$ & $-0,113$ & $-0,076$ & $-0,136$ & $-0,131$ & $-0,223$ & $-0,042$ \\
\hline & p & 0,026 & 0,318 & 0,927 & 0,077 & 0,296 & 0,482 & 0,205 & 0,225 & 0,037 & 0,699 \\
\hline \multirow[t]{2}{*}{ wo } & $r$ & 0,100 & $-0,137$ & $-0,094$ & $-0,108$ & $-0,275$ & $-0,029$ & $-0,049$ & $-0,125$ & $-0,133$ & 0,038 \\
\hline & $p$ & 0,356 & 0,204 & 0,384 & 0,314 & 0,010 & 0,789 & 0,652 & 0,248 & 0,216 & 0,724 \\
\hline \multirow[t]{2}{*}{ CT } & $r$ & $-0,027$ & 0,089 & $-0,107$ & .0,015 & .0,195 & $-0,064$ & 0,026 & 0,099 & $-0,045$ & $-0,081$ \\
\hline & $p$ & 0,803 & 0,410 & 0,322 & 0,892 & 0,069 & 0,551 & 0,808 & 0,356 & 0,675 & 0,453 \\
\hline \multirow[t]{2}{*}{ LP } & $r$ & 0,120 & $-0,023$ & $-0,119$ & $-0,423$ & .0,007 & 0,271 & $-0,238$ & $-0,307$ & $-0,324$ & 0,018 \\
\hline & $p$ & 0,266 & 0,833 & 0,268 & 0,000 & 0,952 & 0,011 & 0,026 & 0,004 & 0,002 & 0,869 \\
\hline \multirow[t]{2}{*}{ AMI } & $r$ & 0,187 & 0,045 & 0,034 & $-0,077$ & $-0,075$ & 0,104 & $-0,092$ & $-0,136$ & $-0,139$ & 0,114 \\
\hline & p & .0,081 & 0,675 & 0,753 & 0,477 & 0,485 & 0,336 & 0,395 & 0,206 & 0,196 & 0,289 \\
\hline \multirow[t]{2}{*}{ LEO } & $r$ & 0,039 & $-0,009$ & $-0,047$ & $-0,435$ & $-0,036$ & 0,014 & $-0,247$ & $-0,263$ & $-0,284$ & 0,086 \\
\hline & $p$ & 0,719 & 0,935 & 0,666 & 0,000 & 0,739 & 0,899 & 0,020 & 0,013 & 0,007 & 0,425 \\
\hline \multirow[t]{2}{*}{ HOS } & $r$ & $-0,018$ & 0,016 & 0,074 & .0,179 & 0,062 & 0,076 & 0,168 & 0,108 & 0,271 & $-0,048$ \\
\hline & p & 0,870 & 0,885 & 0,492 & 0,095 & -0,569 & 0,479 & 0,118 & 0,315 & 0,011 & 0,658 \\
\hline \multirow[t]{2}{*}{ FF } & $r$ & 0,096 & 0,035 & $-0,081$ & $-0,286$ & 0,062 & $-0,093$ & $-0,190$ & $-0,256$ & $-0,312$ & $-0,086$ \\
\hline & $\mathrm{p}$ & 0,374 & 0,749 & 0,452 & 0,007 & 0,569 & 0,387 & 0,076 & 0,016 & 0,003 & 0,425 \\
\hline
\end{tabular}

Capacitatea decizională corelează semnificativ cu vigilența, ca stil de control al stresului adaptativ şi cu eficiența decizională.

Complexitatea cognitivă are o legătură directă semnificativă cu stilul decizional rațional dar şi intuitiv şi o legătură indirectă cu stilul decizional ezitant şi cu evitarea, ca mecanism de control nonadaptativ al stresul decizional.

De asemenea, dimensiunile personalității corelează cu stilul decizional rațional şi cu vigilența ca stil de control adaptativ.

Astfel, factorii cognitivi şi de personalitate sunt în relații de covariere, într-o manieră nuanțată, în raport cu stilul decizional rațional, cu stilul de control adaptativ vigilent şi cu eficiența decizională.

Pentru a aprofunda discutarea relațiilor dintre variabilele modelului propus, s-au realizat trei analize de regresie ierarhică pentru fiecare variabilă dependentă, şi anume: stilul decizional rațional, vigilența, ca stil adaptativ de control al stresului şi performanța decizională - criteriu.
Pentru fiecare variabilă dependentă, variabilele - predictor au fost introduse în trei etape: variabilele cognitive au intrat în prima etapă, variabilele de personalitate în a doua etapă iar în a treia etapă au intrat variabilele de tip control al stresului (cu excepția primei analize în care am comparat doar două modele). În tabelele 4, 5 şi 6 sunt prezentate rezultatele analizei de regresie, incluzând coeficienții beta, $R^{2}$, schimbările în $R^{2}$ după fiecare pas al regresiei şi nivelul de semnificație. Toate analizele de regresie sunt semnificative la $p<.01$.

După cum rezultă din datele cuprinse în Tabelul 4, complexitatea cognitivă este un predictor semnificativ pentru stilul decizional rațional. Prin introducerea variabilelor de personalitate în analiza de regresie, au apărut o schimbare semnificativă a lui $R^{2}$, de la $13,6 \%$ la $22,6 \%$, această diferență reprezentând puterea explicativă a variabilelor, ce sunt considerate, de asemenea, predictori al stilului decizional rațional. 
Tabelul 4. Regresie ierarhică a variabilelor cognitive şi de personalitate în raport cu stilul de decizie rațional

\begin{tabular}{|l|l|l|}
\hline Variabile & asul 1 & asul 2 \\
\hline Capacitate decizională & .018 & .018 \\
\hline Complexitate cognitivă & $363^{\star *}$ & $302^{\star *}$ \\
\hline Aptitudinile cognitive generale & .012 & .110 \\
\hline Potențial managerial & - & $374^{*}$ \\
\hline Leadership & - & $340^{* *}$ \\
\hline Orientare spre aplicarea legii & - & $189^{*}$ \\
\hline$R^{2}$ ajustat & $111^{* *}$ & $180^{* *}$ \\
\hline Schimbări ale $\mathrm{R}^{2}$ & $136^{\star *}$ & $226^{\star *}$ \\
\hline
\end{tabular}

$\mathrm{N}=88 .{ }^{*} \mathrm{p}<.05^{* \star} \mathrm{p}<.01$.

$\mathrm{Vd}$ - stil de decizie rațional

VI1 - variabile cognitive

Variabilele de personalitate, care sunt predictori eficienți ai stilului decizional rațional, sunt potențialul managerial, capacitatea de conducere şi orientarea spre aplicarea legii. Odată cu introducerea variabilelor de personalitate, valoarea lui $R^{2}$ a crescut la $18 \%$, respectiv, variabilele introduse în analiza de regresie explică $22,6 \%$ din varianța variabilei criteriu: stilul de decizie rațional.

Astfel, 22,6\% din dispersia criteriului stil decizional rațional poate fi pusă pe seama acțiunii comune a complexității cognitive şi a celor trei factori de personalitate selectați. Mai mult, diferența dintre cele două valori ale coeficientului de determinare multiplă (R2 schimbare) este de $9 \%$. Această creştere a puterii explicative a modelului estimat poate fi pusă pe seama influenței celor trei dimensiuni de personalitate asupra stilului decizional rațional, fapt reflectat şi de valorile ajustate ale coeficienților de determinare multiplă.

Se poate observa, de asemenea, că acest plus explicativ adus de introducerea dimensiunilor de personalitate în explicarea stilului decizional rațional aduce o schimbare semnificativă statistic, $F(3,101)=3,902, p=$ .01, după ce modelul inițial, bazat doar pe factori cognitivi constituia o soluție predictivă mai bună decât cea bazată doar pe studiul mediei, $F(3,104)=5,467, p=.002$.

Astfel, persoanele care sunt caracterizate prin complexitate cognitivă, având judecată bună, bune în a explica deciziile, care se descurcă eficient cu oamenii, cu aptitudini de conducere, care se descurcă eficient cu stresul şi presiunea, sigure pe sine, care sprijină ferm aplicarea regulilor, care evaluează problemele dintr-un punct de vedere practic, abordează un stil decizional rațional. Acest stil este caracterizat de folosirea logicii şi de abordarea rațională a luării deciziilor. În luarea deciziilor sunt folosite scheme de analiză precum SWOT sau deciziile sunt bazate pe analize a costurilor şi beneficiilor.

Tabelul 5. Regresie ierarhică a variabilelor cognitive, dispoziționale şi stil decizional rațional în raport cu vigilența, ca mecanism de control adaptativ al stresului

\begin{tabular}{|l|l|l|l|}
\hline Variabile & asul 1 & asul 2 & asul 3 \\
\hline Capacitate decizională & $172^{*}$ & $192^{*}$ & $217^{* *}$ \\
\hline Complexitate cognitivă & $243^{* *}$ & $208^{*}$ & 098 \\
\hline
\end{tabular}




\begin{tabular}{|l|l|l|l|}
\hline Aptitudinile cognitive generale & 025 & 012 & 061 \\
\hline Potențial managerial & - & $527^{\star *}$ & $312^{* *}$ \\
\hline Realizare prin independență & - & $194^{*}$ & $178^{*}$ \\
\hline Leadership & - & $385^{\star *}$ & 132 \\
\hline Stil decizional rațional & - & - & $407^{\star *}$ \\
\hline$R^{2}$ ajustat & - & & \\
\hline Schimbări ale $\mathrm{R}^{2}$ & 058 & $179^{* *}$ & $306^{* *}$ \\
\hline
\end{tabular}

$\mathrm{N}=88 \quad{ }^{*} \mathrm{p}<.05 .{ }^{* *} \mathrm{p}<.01$.

$\mathrm{Vd}$-stil vigilent de control al stresului decizional VI1 -variabile cognitive

VI2 - variabile cognitive+variabile de personalitate

VI3 - variabile cognitive+variabile de personalitate+stil decizional rațional

Analizând datele din Tabelul 5, rezultă că variabilele cognitive, în acest caz capacitatea decizională este semnificativă ca predictor pentru vigilență, ca reacție adaptativă la stresul decizional, explicând 9,5\% din dispersia criteriului. De asemenea, variabilele de personalitate, precum potențialul managerial şi realizarea prin independență, sunt predictori semnificativi, $23,4 \%$ din evoluția dispersiei vigilenței putând fi pusă pe seama acestora. Prin introducerea ultimei variabile, stilul decizional rațional, predictorii îşi îmbunătățesc valoarea explicativă, ajungând să explice $35,6 \%$ din varianța criteriului. Puterea explicativă a factorilor introduşi în ultimul model este de 35,9\% pentru vigilență, ca stil adaptativ de control al stresului decizional.

Se poate observa, de asemenea, că plusul explicativ adus de introducerea în model a variabilelor de personalitate în explicarea vigilenței aduce o schimbare semnificativă statistic $F(3,97)=5,880, \quad p=.001$, față de modelul inițial bazat doar pe factori cognitivi (complexitate cognitivă şi capacitate decizională) care constituia o soluție predictivă mai bună decât cea bazată pe studiul mediei $F(4,100)=2,612, p=.04$. De asemenea, introducerea variabilei stil de decizie rațional a adus 0 altă schimbare semnificativă în modelul explicativ al treilea în raport cu cele anterioare $F(1,96)=18,745, p=.000$.

Persoanele cu o bună capacitate decizională, care sunt puțin sensibile la erori decizionale, cu o bună capacitate de analiză rațională a situațiilor decizionale, care utilizează mai puțin euristici decizionale generale, care au bune abilități de conducere, sigure pe sine, puternic motivate să se realizeze în situații fluide şi deschise, preferă activitățile care permit inițiativa şi gândire independentă, bune în definirea propriilor obiective, folosesc analiza rațională în evaluarea alternativelor decizionale, abordează vigilența ca mecanism adaptativ de control al stresului decizional, adică au o capacitate de a interpreta problemele în multiple feluri şi folosesc un număr mare de dimensiuni în realizarea raționamentelor. De asemenea, au o mare nevoie de cunoaştere, respectiv de a procesa informația într-o manieră elaborată. Au mai multă răbdare în definirea scopurilor, colectarea informațiilor, evaluarea alternativelor şi alegerea celor mai potrivite dintre acestea datorita implicațiilor majore pe care le au deciziile adoptate în contextul schimbării organizaționale.

Mediul în care trăim este astfel structurat încât, de cele mai multe ori, sisteme de judecare rapide şi fără efort generează răspunsuri corecte, sistemele corective fiind utilizate în rezolvarea unor situații neobişnuite.

De asemenea, se poate considera că utilizarea unor euristici, în funcție de cerințele sarcinilor decizionale, este o cale prin care indivizi cu o capacitate cognitivă limitată se pot adapta inteligent la medii decizionale complexe (Payne, Bettman şi Johnson, 1993). 
Tabelul 6. Regresie ierarhică a variabilelor cognitive şi dispoziționale, a stilului decizional rațional şi a vigilenței asupra performanței decizionale

\begin{tabular}{|c|c|c|c|}
\hline Variabile & asul 1 & asul 2 & asul 3 \\
\hline Capacitate decizională & 092 & 047 & 059 \\
\hline Complexitate cognitivă & 077 & 137 & 131 \\
\hline Aptitudinile cognitive generale & $252^{*}$ & $167^{*}$ & $164^{*}$ \\
\hline Dominanța & - & $528^{* \star}$ & $518^{* *}$ \\
\hline Realizarea prin conformism & - & $743^{* *}$ & $742^{\star *}$ \\
\hline Eficiență intelectuală & - & $575^{\star *}$ & $583^{* *}$ \\
\hline Toleranța & - & $440^{* *}$ & $442^{\star *}$ \\
\hline Stil de decizie rațional & - & - & 053 \\
\hline Vigilența & - & - & .045 \\
\hline$R^{2}$ ajustat & $056^{*}$ & $222^{* *}$ & 203 \\
\hline Schimbări ale $\mathrm{R}^{2}$ & 093* & $446^{\star *}$ & 448 \\
\hline
\end{tabular}

$\mathrm{N}=88 .{ }^{*} \mathrm{p}<.05 .{ }^{* *} \mathrm{p}<.01$.

VD- performanța decizională VI1 -variabile cognitive $\quad$ VI2 - variabile cognitive+variabile de personalitate VI3 - variabile cognitive+variabile de personalitate+stil decizional+stil de control al stresului

Pe baza datelor din Tabelul 6, în cazul performanței decizionale ca variabilă criteriu, putem afirma că dintre variabilele cognitive doar aptitudinea cognitivă generală este un predictor semnificativ. Dintre variabilele de personalitate, dominanța, realizare prin conformism, eficiența intelectuală şi toleranța îndeplinesc condițiile pentru a fi predictori ai performanței decizionale. Stilul decizional rațional şi vigilența, ca stil adaptativ de control al stresului nu sunt predictori ai performanței decizionale. Configurația de variabile studiată prin analiză de regresie corespunzătoare celui de-al doilea model explică $44,6 \%$ din varianța performanței decizionale.

Introducerea variabilelor de personalitate a generat un plus explicativ asupra performanței decizionale reflectat de schimbarea semnificativă statistic $F(26,74)=$ $1,818, p=.02$, față de modelul inițial bazat doar pe factori cognitivi care este semnificativ mai bun ca soluție predictivă față de cea bazată pe studiul mediei $F(4,100)=2,555, \quad p=.04$. Introducerea variabilelor de tip stil (stil decizional rațional şi vigilență, ca stil de control al stresului) nu a adus un beneficiu explicativ modelului, schimbarea fiind nesemnificativă statistic $F(2,72)=.119, p=.888$.

Astfel, persoanele capabile să reprezinte mai multă informație în spațiul cognitiv în care se procesează datele care ghidează comportamentul, care sunt capabile să învețe mai repede din experiențele pe care le au şi sunt capabile să achiziționeze mai eficient cunoştințe şi abilități de muncă, le place să fie responsabile, sigure pe sine, orientate spre sarcină, cu deprinderi de muncă eficiente, motivate de realizări în mediul clar structurat, respectuoase cu drepturile şi convingerilor altora, sunt performante în sarcinile de luarea deciziilor la nivelul organizației studiate.

\section{Concluzii}

Acest model are deopotrivă valențe explicative, cât şi predictive. S-a realizat testarea lui prin analiză de regresie ierarhică 
multiplă pentru a observa influența factorilor cognitivi şi a variabilelor de personalitate asupra performanței decizionale. S-a decis să folosim regresia ierarhică pentru a putea controla influența variabilelor cognitive şi a celor de personalitate asupra performanței decizionale şi a variabilelor intermediare: stil decizional rațional şi vigilența, ca mecanism adaptativ de control al stresului decizional. În fiecare dintre cele trei modele ierarhice, variabila dependentă este, pe rând, stilul decizional rațional, vigilența şi performanța decizională.

Predictorii incluşi în primul pas au fost: aptitudinile cognitive generale, complexitatea cognitivă şi capacitatea decizională, pentru a putea controla efectul acestora asupra variabilelor dependente. În al doilea pas, pe lângă aceşti predictori, au fost introduse variabilele de personalitate. În al treilea pas, la ultimele două modele, acestor predictori li s-au alăturat variabilele de tip stil: stil decizional rațional (în modelul al doilea şi al treilea) şi vigilența (în modelul al treilea).

La nivel analitic, din modelul estimativ final, se observă că nivelul aptitudinilor cognitive generale influențează performanța decizională. Alături de nivelul intelectual general, am identificat câteva dimensiuni ale personalității ce pot fi considerate predictori buni ai performanței decizionale. Stilul decizional şi stilul de control al stresului decizional nu sunt predictori eficienți ai performanței decizionale.

Din analiza modelelor anterioare, observăm că variabila complexitate cognitivă îşi dovedeşte eficiența ca predictor pentru stilul decizional rațional, alături de dimensiuni specifice ale personalității managerilor (potențial managerial, abilități de conducere şi orientare spre aplicarea legilor). De asemenea, modelul al doilea evidențiază capacitatea decizională ca predictor al vigilenței, respectiv a variantei adaptative de control a stresului decizional, alături de dimensiuni ale personalității (potențial managerial, realizare prin independență, capacitate de conducere).

Factorii cognitivi, în diferitele lor aspecte măsurate, şi-au dovedit viabilitatea ca predictori ai dimensiunilor modelului studiat. În condiții de adaptare la schimbare intervin variabilele cognitive mai nuanțate. Astfel, complexitatea cognitivă este predictor al stilului decizional rațional iar capacitatea decizională este predictor al stilului adaptativ de control al stresului, vigilența.
În condiții de incertitudine, competențele cognitive (descrise în termeni comportamentali), alături de factorii de personalitate prezic cel mai bine eficiența şi performanța organizațională decizională.

În condiții de stabilitate, legătura dintre performanța decizională şi aceste competențe cognitive dispare. Astfel, în condiții de activitate curentă, aptitudinile cognitive generale şi-au demonstrat viabilitatea ca predictori ai performanței decizionale.

$$
\text { Dimensiunile de personalitate }
$$
contribuie însă semnificativ la explicarea şi predicția performanței decizionale, în condițiile în care au fost eliminate influențele determinate de aptitudinile cognitive generale, complexitatea cognitivă şi capacitatea decizională. Adică, în condițiile în care vrem să selectăm o persoană pentru o funcție de conducere, care să obțină performanțe în luarea deciziilor şi avem mai mulți candidați cu nivele relativ egale ale nivelului intelectual general, capacitate decizională şi complexitate cognitivă asemănătoare, dar care diferă în privința trăsăturilor de personalitate, aceştia vor avea performanțe decizionale diferite.

\section{Rezumat}

Acest studiu are ca scop evidențierea influenței factorilor cognitivi şi non-cognitivi asupra eficienței decizionale, prin construirea şi testarea unui model teoretico-explicativ. Acest model reflectă legătura dintre variabilele cognitive, variabilele de personalitate şi performanța decizională. Participanții la cercetare sunt 88 de manageri din cadrul unei organizații cu profil IT\&C, cu vârsta medie de 32.3 ani şi o vechime medie în muncă de 8.6 ani, între care $74,9 \%$ bărbați şi $25,1 \%$ femei.

Instrumentele utilizate includ Inventarul Psihologic California (forma compusă din 260 itemi), un chestionar pentru evaluarea stilului decizional, un chestionar de luare a deciziilor, Testul de capacitate decizională (BTPAC), testul standard Raven, forma Plus, un chestionar pentru evaluarea complexității cognitive şi chestionarul Melbourne de luare a deciziilor. Pentru a evalua performanța decizională a fost construită $\mathrm{o}$ scală $\mathrm{cu}$ ancore comportamentale.

Evaluarea competențelor cognitive, definită în termeni comportamentali ca performanță în luarea deciziilor, alături de dimensiunile de personalitate, ne ajută în selectarea managerilor cu o orientare adaptativă crescută spre schimbarea organizațională şi o performanță decizională bună.

Cuvinte cheie: performanță în luarea deciziilor, complexitate cognitivă, schimbare organizațională 


\section{Bibliografie}

Anderson, N, Cunningham-Snell, N. (2000) Personnel selection. In Chmiel, N., (ed), Introduction to work and organiyational psychology. An European perspective, Blackwell.

Flynn, J.R. (1987). Massive IQ gains in 14 nations: What IQ tests really measure. Psychological Bulletin, 101, 171-191.

Gough, H.G. (1987). Manual for the California Psychological Inventory. Palo Alto, CA: Consulting Psychologists Press.

Hunter, J. E., Schmidt, F.L., Rauschenberger, J.M. \& Jayne, M.E.A. (2001). Intelligence, motivation, and job-performance. In C. L. Cooper\& E.A. Locke (Eds.), Industrial and organizational psychology (pp.278-303). Oxford, UK: Blackwell.

Hunter, J.E. (1986). Cognitive ability, cognitive aptitudes, job knowledge and job performance, Journal of Vocational Behavior, 29, 340-362.

Janis, I.L., Mann, L. (1977). Decision making. New York: Free Press.

Jensen, A. R. (1980). Bias in mental testing. New York: Free Press.

Kline, T.J. (1996). A task for use in decision-making research and practice, Person individual differences, 21, 6, 1077-1079.

Loo, R. (2000). A Psychometric Evaluation of the General Decision-Making Style Inventory, Personality and Individual Diferences, 29, 895-905.

Payne, J.W., Bettman, J.R., Johnson, E.J. (1993). The Adaptive Decision Maker, Cambridge Univ. Press.

Pitariu, H.D. (2000). Managementul Resurselor Umane - Evaluarea performanțelor profesionale, ed. a II-a. Bucureşti: ALL Beck.

Pitariu, H.D., Iliescu, D. (2006). Inventarul Psihologic California, Bucureşti: Psiho Cover.

Pitariu, H.D. (2004). OK - dar ce facem acum? Teoretic şi aplicativ în psihologia contemporană. Revista de psihologie organizațională, 4, 3-4, Polirom.

Schmidt, F.L. (2002). The role of general cognitive ability and job perfromance: Why there cannot be a debate. Human Performance, 15, 187-210.

Schmidt, N., Borman, W.C. (Eds). (1993). Personnel selection in organizations. San Francisco: Josey Bass.

Scott, S.G., Bruce, R.A. (1995). Decision-making style: the development and assessment of a new measure. Educational and Psychological Measurement, 55, 5, 818-831.

Tversky, A., Kahneman, D. (1973). Availability: A heuristic for judging frequency and probability. Cognitive Psychology, 5, 207232.

Vîrgă, D., (2004). Eficiența decizională în contextul schimbării sarcinii. Revista de psihologie organizațională, 4, 3-4, Polirom.

***, 2003, Bateria de teste psihologice de aptitudini cognitive, Cluj Napoca: ASCR.

***, 2003, Manualul testului Raven Standard Plus. 